\title{
La misión en la Iglesia latinoamericana actual
}

\section{Pedro Trigo, \\ Centro Gumilla, \\ Caracas, Venezuela.}

1. ¿Es conveniente que la Iglesia latinoamericana asuma hoy la misión al estilo apostólico?

En el siglo XVI, en el ambiente de la primera evangelización americana, se discutía ardorosamente sobre la aplicabilidad de la misión more apostólico, coincidiendo todos, sin embargo, en que como modelo ideal era no sólo el más excelente, sino un horizonte indeclinable para la Iglesia de todos los tiempos. Al hablar de la misión al estilo de los apóstoles, se referían a la misión prepascual, a la que Jesús envió, según los sinópticos, a los Doce y a otros setenta y dos. Pues bien, retomando esa discusión de antaño, que se retoma sin falta en todas las épocas de reforma de la Iglesia, nos planteamos la pertinencia de la misión, según el estilo apostólico, para nuestra Iglesia latinoamericana actual.

Nos lo planteamos porque no es ésa la práctica habitual de la institución eclesiástica latinoamericana, y porque pensamos que es una llamada de Dios muy precisa, porque sin esa misión no se consolidará nuestra fe, ni se reinsertará la institución eclesiástica en el seno del pueblo de Dios, ni asumirá el pueblo de Dios sus carismas personales, ni se realizará la Iglesia entre nosotros como fraternidad cristiana abierta, fundada en el conllevarnos en la fe y en la vida cristiana.

Actualmente, no realizamos esta misión, porque no somos una Iglesia de convertidos, y por tanto, una Iglesia confesante, sino una Iglesia establecida, y por tanto, una Iglesia identificada con la institución eclesiástica, que tiende a considerar a los cristianos no pertenecientes a ella, es decir, a los laicos, como clientes o usuarios o destinatarios de sus servicios, y tiende a equiparar su radio de acción con la sociedad. Ella actúa, como las otras instituciones establecidas, a través de sus centros (templos, casas parroquiales con sus diversas dependencias, colegios y otras instituciones regentadas por religiosas y religiosos) y a 
través de declaraciones por los medios de comunicación o mensajes transmitidos por sus propios medios: cadenas de televisión y de radio, periódicos...

- La misión al estilo de la que presentan los evangelios (Lc 9, 1-6; 10, 1-11; Mt 10, 1-15; Mc 6, 6-13) tiene parecido más bien a la que realizan espontáneamente algunos cristianos populares y a la que llevan a cabo, de un modo organizado y bastante compulsivo, las Iglesias libres evangélicas y pentecostales, que suelen ser denominadas peyorativamente sectas, así como grupos más marginales al cristianismo, como son los Adventistas y los Testigos de Jehová.

Esta misión recoge algunos aspectos medulares de la misión apostólica, aunque tal vez distorsione otros. No es fácil, por eso, hacer un balance de sus resultados. Tampoco podemos incluir, sin simplificar demasiado los hechos, a estos grupos en un solo conjunto. Pero sí queremos insistir en que los elementos que retienen de la tradición apostólica son en sí salvadores, y por eso, en los casos en que ellos pesan más que los otros, esa salvación acontece, en efecto, como lo podemos comprobar en no pocas personas.

Como por otra parte esos elementos no están enfatizados en la práctica católica, no parecería cristianamente congruente criticar sus desviaciones, hasta que no practiquemos nosotros esa misión, superándolas.

Sin embargo, no sería sano emprender una misión católica con una finalidad competitiva respecto de esos otros grupos cristianos, y menos acertado sería todavía copiar o adaptar sus métodos, en base al número de adeptos ganados con ellos.

Creemos que debemos ponemos en estado de misión, porque nos lo pide perentoriamente el Señor. Y si ésta es la fuente de la misión, el modelo no puede ser otro que el de la misión prepascual. El Señor nos lo pide, porque comunicar su presencia viva es una consecuencia natural de experimentarla como salvación, y asf una prueba decisiva de que esa experiencia existe. Pero, además, en nuestro ambiente se da una sentida necesidad y un deseo profundo, confusamente expresado, pero muy presente, del Dios de Jesús, tanto como vacío y angustia, cuanto como búsqueda insaciada, que pasa de una experiencia a otra, por estar atraídos, secretamente, por el único que en verdad puede saciar el corazón.

La constitución de verdaderos sujetos (ver Trigo) es una necesidad perentoria, tanto social como política. Para lograrlo, son posibles y convenientes muy diversas motivaciones y caminos. El sujeto no puede realizarse sino pluridimensionalmente. Pero un motor, tanto para asumir responsabilidades de un modo radical, como para expresarse en diversos niveles es, sin duda, ese encuentro trascendente al cual tiende la misión.

Restaría decir que los síntomas de que se ha roto la solución de continuidad en la trasmisión ambiental de la fe son ya inocultables, en nuestra América. En 
las jóvenes generaciones es ya masivo el hecho de que no han recibido la primera evangelización, y por tanto, son minoría los evangelizados en su familia y en su entorno. Por tanto, si esta misión que proponemos no se lleva a cabo, América Latina dejará, antes de veinte años, de ser un continente ambientalmente cristiano. Esta previsión no es, sin embargo, ningún motivo para emprender la misión, y no da fuerzas para llevarla a cabo. A lo más, puede dar lugar a campañas de propaganda para lograr adherentes. Pero los ganados así no serán convertidos, ni personas de fe, sino a lo más miembros de una institución. Sólo una llama prende a otra llama, sólo la fe viva, que se realiza en el amor solidario, es capaz de contagiar la fe. Éste es el único motivo para lo que proponemos.

\section{La misión en los evangelios}

Tras exponer el sentido de nuestro planteamiento, pasamos a preguntamos cómo fue esa primera misión prepascual. Ya hemos mencionado los textos fundamentales. Aunque también es pertinente mencionar otros del corpus paulino que dan cuenta de una verdadera tradición: 1Corintios 9,$14 ; 10,27$; y 1 Timoteo $5,18 \ldots$

\subsection{Jesús envió a sus discípulos a misionar}

Empezaremos ante todo asentando el hecho mismo de esta misión. No se apoya, ciertamente, en los relatos, que son redaccionales y con diversos objetivos, en cada uno de los tres evangelistas. Pero sí se apoya en los materiales que expresan el contenido de la misión y el modo de ella, que provienen de colecciones orales, que luego fueron recogidas diversamente por la "fuente" (Q), común a Mateo y Lucas, y por materiales propios, tanto de Marcos como de Lucas e incluso de Mateo. Los exegetas coinciden en que, respecto de la misión, los materiales más originales serían los de $\mathbf{Q}$ y, además, en la versión de Lucas, pero asumen como complementarios algunos otros, por ejemplo, la restricción de la misión a Israel, que explana Mateo.

Una prueba aducida a favor de su historicidad es la convergencia de fuentes. Asf, Taylor: "Lo que determina el valor histórico de este acontecimiento es el testimonio combinado de Marcos, $\mathrm{Q}, \mathrm{M}$ y L" (p. 350, cfr. p. 354; ver además Bovon, p. 639, y más aún, Crossan, p. 384, para quien la misión es la unidad evangélica más atestiguada, p. 496). Otro indicio fehaciente sería para Jeremias el contenido de la misión, que es la inminencia del reino y la conversión, y no la persona de Jesús: "La ausencia total de cristología en el encargo que se da a los mensajeros hace muy probable que nos encontremos aquí con una tradición prepascual" (p. 270).

Otros exegetas ven la impronta indudable de Jesús de Nazaret en el tono y el modo de la misión. Dice Bovon: "Estos preceptos del radicalismo evangélico quizás se observaron al pie de la letra en los primeros tiempos por ciertos predi- 
cadores itinerantes y reflejan sin duda la exigencia escatológica y polémica del Jesús histórico, pero perdieron luego una parte de su actualidad" (p. 643). - Theissen insiste muy fuertemente en estos predicadores ambulantes, molestos y aun revulsivos, como fuente, tanto de estos logia como sobre todo del propio estilo de Jesús, que continuaron: "Su radicalismo ambulante se remonta al mismo Jesús" (pp. 25-26). Así, pues, esa tradición no sólo es materialmente exacta, sino que "es existencialmente auténtica" (p. 26). Gnilka se refiere al radicalismo y a la tensión escatológica y, por estas razones, concluye que las "instrucciones misioneras' de los sinópticos se basan en un núcleo de logia que proviene de Jesús" (p. 281). También para Bonnard, la urgencia apostólica "tiene sus raíces en la urgencia del mismo Jesús" (p. 222).

Para Hengel, "será muy diff́cil dudar del suceso histórico del envío de los discípulos por parte de Jesús" (p. 108). La razón para él es mucho más comprehensiva. Va descartando tipos de discipulado que no se corresponden con el que Jesús propone a sus discípulos. Y concluye: "La crudeza de la exigencia de Jesús para con la persona llamada por él a seguirle se explica solamente por su destino al servicio del reino. Este servicio tenía que darse del mismo modo que Jesús lo realizaba, es decir, en el anuncio del reino próximo de Dios y del acontecimiento salvifico. Los discípulos obtienen participación inmediata en la obra de Jesús: '...no son sólo sus mensajeros, son sus colaboradores'" (p. 110). Citemos para concluir a Léon-Dufour, que asienta que "la difusión del evangelio no está reservada a la comunidad apostólica: ya la había inaugurado la comunidad prepascual" (p. 108). "La 'misión prepascual' es un hecho reconocido como verídico por el conjunto de los críticos" (p. 306).

\subsection{La misión apostólica es participación real de la misión de Jesús}

Ya la afimación del hecho nos ha puesto sobre la pista de su sentido. Desentrañémoslo, antes de entrar en el análisis de cada uno de los elementos. Hengel, citando a Hahn, considera que la misión de los discipulos es participación interna de la misma misión de Jesús. Sólo eso justifica las exigencias radicales del seguimiento. Por eso, para él, la misión no fue un acontecimiento excepcional (p. 119). Del mismo modo, insiste Bomkamm en que las exigencias que conlleva la llamada y, por tanto, la llamada misma "no se justifica más que en función del reino de Dios" (p. 155). "Anunciar la proximidad del reino y manifestar su fuerza salvadora ya presente es el servicio por el que los discípulos deben estar dispuestos a aceptar la pobreza y el sufrimiento (Mt 10, 6 ss.)" (p. 156). Gnilka también subraya esta pertenencia interna de la misión al acontecimiento del reino; es decir, que los apóstoles no sólo hacen igual que Jesús siguiendo su ejemplo. La ayuda de Dios en las curaciones y exorcismos "demuestra la imupción de la soberanla de Dios" (p. 281). En el mismo sentido, dice Taylor que no fue un simple viaje para predicar, ya que ellos son "heraldos encargados de proclamar el mensaje" (p. 353). Eso mismo explana Bonnard. En 
este segundo discurso, dice, describe Mateo a los heraldos del reino y las instrucciones que les da Jesús. "El nexo literario e ideológico con lo que precede es evidente: si los capítulos 5-7, con su complemento narrativo de los capítulos 8 y 9, estaban dominados por la idea de la autoridad de Jesús como intérprete de la ley y su relación con las autoridades religiosas (fariseos) y endemoniados (enfermedades) de su tiempo y de su pueblo, esta nueva parte nos presenta la misma autoridad dada $(10,1)$ por Jesús a los apóstoles" (p. 221). Lo mismo insiste León-Dufour. Para él, también las curaciones y los exorcismos eran "la prueba de que estaban habilitados para anunciar el reino" (p. 309). En este sentido, habría que entender la identificación entre los heraldos o mensajeros y el maestro que los enviaba (p. 307).

Jeremías especifica el sentido de esta autoridad: "Servir como mensajero es un acontecimiento escatológico" (p. 277). De ahí, la autoridad que se les concede: "son portadores de la salvación de Dios" (Ibid.). Por eso, pueden transmitir realmente la paz de Dios: "Son partícipes de la victoria de Cristo sobre Satanás" (Ibŕd.). O sea, que la autoridad sobre las enfermedades y los espíritus es la participación del Espíritu Santo ( $(b i d)$. A esta conclusión llega también Bornkamm: "Hemos de tener en cuenta ciertamente la influencia que ha podido tener la experiencia de la comunidad primitiva en la presentación de los discípulos, de su misión y de su actividad suscitada por el Espíritu. Pero eso no excluye de ninguna manera que el Jesús terrestre haya hecho participar de su poder a sus discípulos" (p. 156).

Según esto, habría una continuidad fundamental entre la misión prepascual y postpascual. Ambas son participación de la misión de Jesús y por iniciativa suya. Y en ambas es decisiva la fuerza (exousía, dynamis, energeia) del Espíritu. Ella es el sello de su autenticidad, la prueba de que la participación es intema, real y no una mera referencia contenidista, a contenidos. Dicho negativamente: una misión cuyos contenidos conceptuales sean los mismos que emitía Jesús, pero que carezcan de esa fuerza interior, de ese dinamismo espiritual, de esa energía salvadora, no es la misión de un enviado de Jesús, no prosigue realmente su misión; es externa al acontecimiento que la misión puso en marcha.

Desde este punto de vista, habría que matizar tremendamente la contraposición tan difundida, según la cual Jesús de Nazaret predicó el reino y los apóstoles predicaron a Jesús. Ya Jesús ligó el reino a su acción salvadora, que lo hacía presente sacramental y germinalmente; y por su parte, los apostoles hablan de Jesús resucitado como el inicio de la humanidad definitiva y de la vida eterna. Su exaltación como primogénito nuestro significa la inauguración en su persona de ese reino, que él anuncí, prefiguró y sembró con lo que hizo y dijo, y más radicalmente, con su presencia solidaria y fiel.

Pero, como sugiere León-Dufour, ya la misión prepascual contenía no sólo la trasmisión de palabras de Jesús, sino el relato de sus acciones como anuncio y 
confirmación de ese reino, que era el contenido de la misión prepascual (pp. 309-314).

Hengel da un paso más en esta dirección: los discípulos se sentían tan dentro del acontecimiento que debran proclamar que no se sintieron en la obligación de atenerse únicamente a la literalidad de los logia de Jesús. Claro está que en la misión prepascual está la fuente de la Fuente $(Q)$, que fue codificada después, pero también en la misión prepascual se da la fusión entre lo de Jesús y la experiencia salvadora que habían tenido los discípulos al dejarlo todo para seguirlo, en orden a ese reino que él anunciaba con poder y hacla presente con su presencia desnuda y pobre, pero providente (pp. 117-121).

Según esto, en la misión se trataba de lo de Jesús: lo que decía y la fuerza salvadora con que lo hacía presente. Pero se trataba inseparablemente de lo de Jesús, "según ellos", según habían sido afectados y salvados por el acontecimiento de Jesús. Ellos no eran grabadoras, ni máquinas fotográficas, ni proyectaban la pelicula de Jesús. Eran los transformados por él. Por eso, sus personas eran tan inherentes a la misión como la persona del propio Espíritu. Era elemental que para ellos no había ningún peligro de colocarse en el centro y sustituir sutilmente a Jesús. Querían, por el contrario, testimoniar con sus vidas la fuerza salvadora del reino, que irrumpe en Jesús.

Prosiguiendo con el objetivo de aprehender el sentido de la misión, queremos referimos al aporte de Schnackenburg. Para él, "lo que Jesús entonces puso en marcha fue un 'movimiento de reunión'. El quería reunir al Pueblo de Dios para que, escuchando su doctrina, entrase en el reino de Dios. Como hombres, tenían que escuchar su doctrina de salvación, creer en ella y volverse hacia Dios con todo su corazón" (p. 113). Creemos que este aporte es capital. Cada quien tiene que abrir a Dios su corazón, de modo que Dios reine en él, como es su designio. En este sentido, Jesús predica ante todo el reinado de Dios. Pero quien acepta su reinado y se vuelve a él, también se vuelve al hermano para que también él lo acepte. Éste es el primer significado del movimiento que Jesús induce. Pero al volverse unos a otros y al ir aceptando unos y otros ese reinado, se va formando un ambiente social; y esto dice ya relación al reino como magnitud objetiva, como anticipación de él. Se va formando el pueblo de Dios como reunión de los hijos de Dios, que estaban dispersos. En este sentido amplio, "son muchas las veces que oímos en los evangelios sinópticos que una multitud del pueblo lo 'seguía"' (p. 114).

Sin embargo, en los evangelios aparece un seguimiento especial, el de los discípulos, que tiene "la finalidad de cooperar con este movimiento de reunión de Jesús [...]. Esta misión conforma, de una manera mucho mayor, toda su vida" (Ibrd).

Pero hay que recalcar que las exigencias del reino son iguales para todos. Ellas son "la voluntad de ser para Dios, de entregarse íntimamente a su servicio 
(Mt 6, 24), de buscar el reino de Díos y de dejar todo lo demás al cuidado del Padre (Lc 12, 29 ss.)" (p. 114). "La relación primitiva de los discípulos es, pues, realmente un símbolo de lo que significa "el seguimiento de Jesús"' (p. 117).

Crossan insiste, con todo el vigor del cual es capaz, en que Jesús viene a poner en marcha un movimiento que, por un lado, se remite a Dios y, por otro lado, saca de esa fuente una alternativa a la estructuración social de todo el mundo mediterráneo, basada en una red jerarquizada de intermediarios, que instauran un modo de relación clientelar. Su movimiento crea "el igualitarismo compartido de los recursos espirituales y materiales. Me gustaría recalcar este hecho lo más posible, e insisto en que no podemos separar su materialidad y su espiritualidad, su naturaleza fáctica y su simbolismo" (pp. 393-394). "Por eso, la apariencia de la indumentaria y demás accesorios era tan importante como la aceptación de la casa y la mesa" (p. 397). Lo fundamental para Crossan, es insistir a la vez en el alcance social, polftico y de horizonte vital de esta iniciativa de Jesús, y en la determinación con la cual Jesús lo ligaba al designio de Dios, que él hacía presente. En la pretensión religiosa de esta alternativa radicaba su carácter revulsivo. Ésa era, según Jesús, la salvación de Dios. Más aữn, ese movimiento lo revelaba y comunicaba realmente. Así, pues, el centro del movimiento no era el propio Jesús, sino la presencia de Dios como salvación para la gente. Pero él era el portador de esta revelación.

Desde este punto de vista, es obvio que la misión no es un hecho puntual: "quizá constituyera un fenómeno más o menos típico para todos aquellos que desearan participar de una manera especialmente activa en el movimiento de Jesús" (p. 386).

Hay aquí, pues, entrañado un modelo religioso alternativo al que representaban las autoridades religiosas del templo y de la sinagoga. Y el meollo consiste en la propuesta de inmediatez de Dios. La mediación de Jesús cancela los intermediarios. El resultado no es el solipsismo de Dios con cada alma, sino un mundo de hermanos. Trataremos de desentrañar esta propuesta.

\subsection{El modo de la misión expresa y realiza su sentido}

Tras haber asentado el hecho histórico de la misión prepascual y su sentido, vamos a referimos a sus condiciones materiales.

\subsubsection{Los mensajeros son enviados en binas}

Comencemos por el envío en parejas. Taylor lo relaciona sencillamente con la costumbre judia: "Los discípulos de Juan Bautista (cfr. Lc 7, 18; Jn 1, 37) y, en la Iglesia primitiva, Bernabé y Pablo, Pablo y Silas, etc., adoptaron la costumbre judía de viajar de dos en dos" (p. 352). Jeremias precisa que "el enviar a los mensajeros en parejas, costumbre que no puede probarse todavía en el 
Antiguo Testamento, era una usanza firmemente arraigada en el judaísmo antiguo" (pp. 274-275). Da dos razones para este proceder. La primera sería la protección mutua; la segunda, que uno confirmara las palabras del otro. Cita Hechos 14,12 y se remonta a la cláusula legal de Deuteronomio 17,$6 ; 19,15$, aplicada originalmente a los testigos, y que llevaría a entender la misión como un emplazamiento. Schmid se refiere también a la función de testigos y añade, además, "para su mutuo consejo y ayuda" (Mc 174). Eso mismo dice Gnilka, asentando que "corresponde a la praxis de la misión cristiana" (p. 278). Crossan, citando a Liefeld, afirma que no hay testimonios rabínicos antes de la destrucción del templo, cosa que subrayaría Fitzmyer, al caracterizar esta costumbre como típica de la tradición rabínica posterior (p. 386).

Según esto, si no se explica por la práctica judía, ni es proyección de la usanza posterior de la Iglesia, si por el contrario puede remontarse a Jesús, como se podría conjeturar también por la enumeración de los apostoles en binas (cfr. Jeremias, $o p$. cit.), tendríamos que preguntamos por las razones de fondo. La defensa, o la ayuda, nos parecen motivos de refuerzo, no de fundamentación. El de atestiguar tiene más peso, si la misión escatológica tiene un cariz apocalíptico, ya que con él sí cuadraría el emplazamiento. Pero nos parece que no es éste el caso. Bonnard apunta, pensamos, en la dirección correcta, cuando observa que "Jesús no autoriza o diviniza a ciertos individuos anónimos. Comunica su autoridad a un grupo concreto de discípulos (Mt 9, 37) o de apóstoles (Mt 10, 1)" (p. 221). Todavía tendríamos que indagar por el sentido de tal preferencia. Para nosotros tendría que ver con el objetivo de fondo de la misión. Si se trata de un movimiento de reunión, no es una persona sola la más apropiada para reunir; son más bien los hermanos, los que pueden reunir en una familia a los hijos de Dios, que estaban dispersos. Por eso, Marcos y Juan comienzan el evangelio con la constitución, por parte de Jesús, de ese grupo, germen de la convocación (Mc 1, 16-20; Jn 1, 35-51). Por eso, al acabar el sermón de Pedro en pentecostes, anota Lucas, emblemáticamente: "se reunieron al grupo unos tres mil" (Hch 2, 41). La conversión a Dios, la aceptación de su reinado en la propia vida lleva, por su misma dinámica, a sumarse al movimiento de Jesús y asociarse de un modo u otro al grupo de sus discípulos.

\subsubsection{Prohibición de llevar pertrechos}

Respecto de los pertrechos parece que hay acuerdo en considerar más original el radicalismo de $Q$ que la mitigación de Marcos ( $c f r$. Taylor, p. 352; Gnilka, pp. 278-279). En resumen, el equipamiento se reduce a una túnica. Se rechaza el morral, la bolsa, las sandalias y el bastón. Podriamos preguntar por qué se excluyen de modo expreso estos elementos, al parecer tan mínimos e indispensables. Parece evidente que se trata de una comparación implicita, es decir, que se quiere descartar el parecido con otros tipos de personas itinerantes, 
conocidas en esos ambientes. Tres serían los que mencionan los exegetas: los mendigos, los peregrinos del templo y los filósofos cínicos.

La mendicidad estaba basada en algún tipo de minusvalía: como el mendigo no tenía cómo obtener lo necesario por sí mismo, sobrevive pidiendo a otros. Si en un pueblo pequeño la gente, por lo general bastante pobre, tiende a cansarse de darle, el mendigo pide, recorriendo la comarca. Lo que tiene lo lleva consigo y suele estar viejo y gastado, tanto ropa como calzado; lo que no lleva puesto lo echa a la alforja. El bastón es útil para apoyarse y para defenderse.

No puede dudarse de la proximidad de estas personas, tanto respecto de Jesús como de sus enviados. Proximidad en el sentido más físico: coincidirfan muchas veces por los caminos; proximidad, más aún, como destinatarios predilectos del mensaje del reino: ellos eran los más pobres entre los pobres (cfr. Lc 6, 20-21). Jesús curó a muchos de ellos (Lc 18, 35-43; Jn 5, 2-14; 9, 1-38) y los señal6 como comensales del banquete del reino (Lc 14, 21-23). También, como los mendigos, experimentarían los mensajeros no pocas veces el rechazo y pasarian privaciones. Todavía se parecían a ellos en cuanto que para su sustento, dependían de la benevolencia de la gente. Pero había una diferencia radical: el punto de partida no era la minusvalía, sino la entrega al único necesario y la solidaridad. Esta diferencia se traducirfa en la figura: es verdad que los enviados llevaban sólo una túnica, pero no iban de vencida; no habla en ellos resignación, ni abandono. Por el contrario, estaban llenos de vida y poseidos por la urgencia de lo que tenían que comunicar. No despreciaban, de ningún modo, a los mendigos; más bien, eran buena nueva para ellos. Pero ellos no eran mendigos, aunque al primer golpe de vista podía confundírselos.

Se ha asociado a Jesús, a sus enviados prepascuales y a los predicadores itinerantes de la primera hora cristiana con predicadores ambulantes, que eran a la vez curanderos y filosofos, personajes bastante habituales y notorios, en el mundo del helenismo (es la tesis, por ejemplo, de Theissen). Entre estos, los más numerosos y radicales serían los cĺnicos, que, se asegura, estaban presentes en la Galilea que conoció Jesús, que contenfa ciudades bastante helenizadas, comenzando por Séforis, distante sólo seis kilómetros de Nazaret (así Bovon p. 644 y Gnilka p. 279, con bibliografía). Crossan lleva tan adelante la comparación que llega a caracterizar a Jesús como "un cínico judío de carácter campesino" (p. 483). Naturalmente que, a lo largo de la obra, matiza fuertemente esta caracterización y la complementa, pero ya sólo la comparación hace ver que hay aquí un filón interesante. Si empezamos por la indumentaria, cabe destacar el mayor radicalismo de Jesús y sus seguidores: ni alforja, ni bastón, y la túnica, más práctica, en vez del manto filosofal, más prosopopéyico. De todos modos, en ambos casos es común la desnudez extrema y la itinerancia, no como necesidad (como en el caso del mendigo), sino como libre elección programática, y el sentido revulsivo, de protesta, que significa ese género de vida. 
A nuestro modo de ver, estas semejanzas ayudan a recalcar la contradicción entre ambas propuestas contraculturales. Crossan subraya que el cinismo es la negación de los valores, que pautaban la civilización grecorromana y, más en general, la cultura mediterránea (pp. 110-122). Sin embargo, no deja de ser también la realización extrema de su ideal de autarquía, logrado mediante la práctica de la ataraxia. La consecuencia es la libertad, "que no proviene únicamente de la pobreza física, que en último término haría a la persona inaccesible al deseo y a la añoranza, sino, fundamentalmente, de la pobreza espiritual que hace a la persona insensible a los ataques y a la violencia" (p. 118). Una libertad que el cínico usa para zaherir las esclavitudes de sus conciudadanos y despertarlos así al señorío de sf mismos, en lo que consiste la verdadera realeza.

Es claro que también Jesús demostraba una libertad provocativa, en su proceder y en su modo de relacionarse, y que muchas de sus palabras eran paradojas radicales, que escandalizaban a los instalados. Pero su ethos y su pathos eran totalmente otros. Nadie menos autárquico que Jesús. Es cierto que tampoco se rigió por ninguna heteronomía. Pero su principio y fundamento fue relacional: desde una autenticidad a todo prueba, él se comportó siempre como un Hijo y como un Hermano. Eso fue él y eso buscó que fueran sus disclpulos. Por eso, insisten los comentaristas en que la desnudez del mensajero expresa que "hacen el camino con la tranquilidad de su confianza en Dios (cfr. Mt 6, 25-34), debiéndose confiar a la hospitalidad de aquellos a los que precisan llegar" (Schmid a, p. 175). "Confiere credibilidad a su predicación y da testimonio de su confianza en Dios" (Gnilka p. 279). Jeremias explaya que la pobreza radical es el modo de vivir de fe y de experimentar la patemidad providente de Dios (p. 276).

Tenemos que unir este requisito de la pobreza con el objetivo de la misión. Si se trata de hacer presente el reino, con el dinamismo de vida que posee, sólo quien vive de fe ( $\mathrm{y}$ lo muestra inequívocamente, porque no tiene nada con qué vivir y nadie en qué apoyarse, y sin embargo, vive y no sólo sobrevive) puede testimoniar, fehacientemente, la cercanía absoluta de Dios como fuente de vida. Por eso, siempre que la Iglesia ha vuelto sobre sí misma, para reconfigurarse al estilo de Jesús, convirtiéndose de su desfiguración mundana, ha incluido en su programa la misión desde abajo, en pobreza. Ésta es ya la tesis que plantea Pablo a los Corintios (1Cor 1, 18 - 2, 5).

Respecto a la comparación con el peregrino, debemos distinguir dos momentos de la peregrinación: el camino y el santuario. Taylor apunta en esta dirección: "Después de citar Berakot, IX, 5, donde se manda que nadie 'suba al monte del templo con su bastón, sus sandalias o su alforja', Manson indica que tal vez la misión de los discípulos se considerase empresa particularmente sagrada" (p. 355). Bonnard, tomando la hipótesis de Schniewind, que le parece la mejor fundada, asienta: "Debéis presentaros ante los hombres con el mismo desasimiento que ante Dios (en el templo o en la sinagoga), sin sandalias ni 
bastón. Las personas que ayunaban iban con los pies descalzos y sin bastón" (p. 227). Si entendemos bien, querrían decir que Jesús convierte la misión en una acción litúrgica, sagrada. Obviamente, esto no puede significar una ritualización de la misión, ya que Jesús combate con todas sus fuerzas la ritualización, tanto de la vida como del culto (Mc 7, 1-23). Es cierto que parece propio de Jesús exigir el máximo respeto para con la gente a la cual los enviaba; pero no parece tan genuino de él pedirles que lo expresaran de ese modo.

Bovon insiste también en el punto, pero interpretándolo de otro modo y subrayando la intención polémica que encierra. "En ese caso, Jesús habría cambiado radicalmente el objetivo, el contenido y las condiciones materiales de la peregrinación: en lugar de subir a Jerusalén, se va a los israelitas dispersos; en vez de cumplir con los propios deberes religiosos, se lleva la buena noticia; en vez de las alforjas y el bastón del peregrino, se lleva el equipaje mínimo de los últimos tiempos [...]. Un giro tan radical presupondría una reflexión sobre el lugar de la presencia de Dios, que no estaría ya ligada al templo, sino a la persona del mensajero. Semejante desplazamiento de la santidad, del templo a la persona, corresponde a las convicciones de Jesús y forma parte de la conciencia que tenía de su identidad" (pp. 643-644). Es cierto que hay dichos de Jesús sobre el templo que, según los evangelios, los discípulos no habían entendido, y que después comprendieron, que se referian a su propia persona. En forma de acusaciones, aparecen en el proceso religioso contra Jesús. Que él hace presente a Dios de un modo absoluto parece ser no sólo parte de la autoconciencia de Jesús, sino de la experiencia de los discípulos y de la gente, aunque no fueran capaces de teorizarla. Ahora bien, desde esta perspectiva, tendríamos que es el templo el que peregrina para encontrarse con la gente; es Jesús ( $y$, en tanto que lo representa, su mensajero) el que lleva por doquier la presencia de Dios. Es correcta la consecuencia que saca Bovon de que, si se abre a su visita, "nadie necesitaría frecuentar el santuario" (op. cir.). Pero entonces, sería a los demás a los que se pediría que los recibieran como a Dios (consecuencia que, por lo demás, saca Jesús: Mt 10,40). No se ve por qué los mensajeros, como representantes de Jesús y de su Padre, tendrían que ir, como Dios le pide a Moisés que se presente ante él, en la zarza ardiendo (Ex 3, 4-6).

Así, pues, nosotros mantenemos que la misión es la alternativa a la peregrinación al templo, no verbalizada como tal, pero puesta realmente en marcha. Y que por eso, mantiene el carácter de servicio sagrado; pero una sacralidad no ritualizada, es decir, no como expresión de separación, sino como expresión del peso, de la autoridad, de la energía de vida, que habita en plenitud en Jesús, y que él transmite. Desde este punto de vista, sí sería correcto decir que la fuerza del Espíritu reluce en la debilidad (2Cor 12, 9-10), y que por eso, la desnudez de los mensajeros es totalmente adecuada para trasparentar la fuerza del Dios de vida, que ellos evangelizan como participación del ministerio de Jesús. 
Otra razón que dan los comentaristas de la prohibición de llevar nada consigo tendría que ver con 'el carácter escatológico de la misión, acentuado, si se la -entiende al modo apocalíptico. Así, Taylor: "Todas estas prohibiciones implican que la misión fue muy apresurada. Citamos a continuación unas palabras de Manson p. 181: 'La consecuencia natural es que los misioneros han de ser como un ejército invasor y que han de vivir de lo que encuentren en el campo"' (p. 353). Como se ve, el tono apocalíptico difícilmente puede expresarse de modo más tajante.

Ya vimos cómo, para Bovon, "estos preceptos del radicalismo evangélico [...] reflejan sin duda la exigencia escatológica y polémica del Jesús histórico" (p. 643). Él se refería al "equipaje mínimo de los últimos tiempos" (op. cit.). Añade, para acentuar la referencia al propio Jesús, que "Lucas no entiende quizá ya en su tiempo la intención polémica y apocalíptica del discurso de Jesús, pero comprende muy bien que su Meśas envió a los Doce sin medios humanos, pero seguros de la presencia de Dios" (p. 644). Para Bonnard, la pobreza requerida no se debe a "una preocupación ascética personal, sino porque comienza la siega, porque el fin está próximo y porque el trabajo ha de realizarse con rapidez y libertad" (p. 237). Lo mismo expresa Jeremias: "es la última hora para ofrecer la liberación, la última hora para arrojar la red a fin de congregar a Israel (Mc 1, 17 par., véase Jr 16,16), es la última hora de recoger la cosecha (Mt 9, 37 ss. par.)" (p. 276).

Estas argumentaciones, que los autores aplican también a la prohibición de saludar por el camino, ¿cómo tendríamos que valorarlas? No entramos aquí en la discusión de si el carácter indudablemente escatológico de la figura y el ministerio de Jesús, revistieron para él una configuración apocalíptica. Como quiera que haya sido, el trasfondo permanente es que ante el absoluto de Dios y de su venida a nosotros (no sólo como reino apocalíptico, sino también como reinado en cada persona que lo acoge), todo se vuelve relativo. La cotidianidad deja de ser esa trama espesa, que absorbe y determina. Al abrirse uno a la presencia actual de Dios y a su designio, todo lo demás cede el campo y se pospone, y luego se va reubicando, en tanto es compatible con este designio de Dios y lo expresa. Como el designio de Dios es salvar y plenificar la creación, es imprescindible este segundo momento de reestructuración de una cotidianidad regenerada. Pero como se había perdido el rumbo, y la cotidianidad no expresaba la semejanza de Dios, en la cual habramos sido creados, es igualmente ineludible el momento de ruptura desestructuradora y de afincamiento en el único necesario. La desnudez de los misioneros expresa que han llegado los últimos tiempos de la cercanía absoluta de Dios como fuente de vida; y que por eso, es posible vivir de fe. Por eso, la desnudez no es expresión de un ascetismo voluntarista, sino de que, en efecto, ha sido comunicado el Espíritu de Dios, que renueva la faz de la tierra. Todavfa no ha llegado el reino de Dios, por eso, 
lodavía el justo tiene que vivir de fe (Hb 2, 4; Rom 1, 17). Pero también es cierto que puede vivir de ella. La desnudez de los enviados es testimonio vivo de esa realidad escatológica. Con esto queda precisado el sentido de la confianza en Dios, a la cual antes aludimos. No tiene que ver con un providencialismo atemporal, al estilo, por ejemplo, del de los estoicos, sino con la proclamación escatológica de la venida del reino de Dios, que es el eje central de la predicación de Jesús (Mc 1, 14-15) y de la de sus mensajeros (Mt 10, 7; Lc 9, 2; 10, 9).

\subsubsection{Enviados a las casas}

No cabe duda que los misioneros son enviados a las casas. Con ello están relacionadas las instrucciones sobre qué hacer, tanto si los reciben en ellas como si no los reciben. Así, pues, los destinatarios de la misión no son ni individuos sueltos, ni pueblos congregados como tales, por ejemplo, en las plazas (que como se sabe eran lugares públicos, digamos oficiales) o en las sinagogas. Jesús vino con una función pública. Sean o no palabras de Jesús, la respuesta que da a Anás expresa, certeramente, esta índole no esotérica, sino pública, de su ministerio: "Yo he hablado públicamente a todo el mundo; siempre he ensañado en la sinagoga o en el templo, donde se reúnen los judíos; no he dicho nada a ocultas" (Jn 18, 20). Es cierto que hay instrucciones a los discípulos; pero no esotéricas. Por eso: "lo que escuchan al oído, repítanlo sobre las azoteas" (Mt 10, 27). ¿Por qué lo que dice Jesús se vuelve enigmático? Porque no se acepta el tipo de manifestación de que es portador Jesús y, en definitiva, al Dios al que él revela de modo tan inesperado y con rasgos tan diferentes de los establecidos. De ese modo, Jesús revela lo que había quedado oculto, desde el principio del mundo (Mt 13,35), pero que sigue oculto a los que se lo revela; no sólo a la gente (Mc 4, 10-12), sino también y, en primer lugar, a sus propios discípulos (Mc 4, 13; 7, 18; 8, 17-18; 9, 32), que, sin embargo, siguen con él porque, en medio de su incomprension, han comprendido lo fundamental: que Jesús es el enviado de Dios y como tal portador de vida para ellos y para todos. Esta experiencia será la que autentifica la misión. En este sentido, sí están ellos en el secreto del reino y pueden trasmitirlo sin profanarlo.

¿Por qué la transmisión desde las casas? A nuestro entender, porque es el punto de intersección entre lo personal y lo colectivo, entre lo público y lo privado. El interior de la casa es un espacio privado, pero no individual, y además, ese colectivo personalizado, que es la familia, era en todo el mundo mediterráneo, y particularmente en el pueblo elegido, la célula social primaria. En efecto, Israel era simb́licamente el pueblo de las doce tribus, y cada tribu estaba compuesta a su vez por familias, en las cuales se integraban los individuos. Si la misión es un movimiento de reunión del pueblo de Dios, la reunión se hace desde las familias. Así aparece frecuentemente, tanto en los evangelios 
(Jn 4, 53; Lc 19, 9; Mc 2, 15; 14, 13-14; Lc 10, 38;19, 9), como en los Hechos (Hch $2,4.6 ; 5,42 ; 9,43 ; 10,48 ; 12,12 ; 16,15.31-34 ; 17,5 ; 18,3 ; 19,18 ; 21$, -16) y en las cartas de Pablo.

Pero eso no significa sacralizar a la familia, tal como existía. Por el contrario, la familia tenía que desabsolutizarse y reconstituirse, desde el designio de Dios y abrirse, por tanto, a los demás. No siempre sucedía así, ni mucho menos. Ni siquiera en la propia familia de Jesús (Mc 3, 21; 6, 4; Jn 7, 5). Por eso, Jesús prevé que la misión puede causar divisiones entre las familias (Mt 10, 35-37). Las decisiones que entonces han de tomarse ponen a prueba si en verdad Dios es el centro de la vida y se está dispuesto a reestructurarlo todo a partir de su designio (Lc 9, 59-62). Sin embargo, quien se encuentre en esta coyuntura de tener que posponer $y$, a pesar suyo, romper con su familia que no acepta su opción, debe tener la esperanza de encontrar cien casas, hermanos y madres, por los que dejó (Mc 10, 29-30).

Pero la constitución de la familia de los discípulos (Mc 3, 31-35), en el designio de Dios, que hace presente Jesús, no es una alternativa a las familias étnicas, sino su salvación, aunque de hecho no siempre resulte así, por la ceguera y el egoísmo, que hacen encallar a la libertad humana.

\subsection{Contenido de la misión: la paz}

La propuesta de la paz tendría en Lucas su visión original (Schmid b, p. 259). Jeremias observa que "eirene está representada aquí como un poder que o toma posesión de la casa, o retoma a sus portadores" (p. 270). Para él, esta personificación de la paz sería un rasgo palestino (lbid.). Bornkmann lo asocia simplemente con la idea de salvación (p. 156).

La paz debe estar ya presente en los enviados. Ése sería el sentido de la llamada de Jesús a conservar la paz unos con otros, recogida en las instrucciones a los discípulos (Mc 9, 50). "Los discípulos, como portadores de la salvación, tienen que crear ya desde ahora una comunidad de paz" (Hasler, pp. 1201-2). La bina, como representante de la comunidad de Jesús, tiene que ser portadora de la paz.

Ésta, en las instrucciones prepascuales, aunque incluya la armonía comunitaria (cfr. 1Tes 5, 13; 2 Cor 13,11) y, por supuesto, con los demás (cfr. Rom 12,18), no se refiere directamente a ella. Su ámbito, como señalaban los comentaristas mencionados, es netamente escatológico. "Se sitúa a la última generación de Israel ante una elección definitiva. No hay que entrar en ninguna ciudad y en ninguna casa sin hacer la promesa de la salvación en forma de un saludo de paz o de la salutación angélica (Dan 10, 19; Tob 12, 17). El que la acepte, será un 'hijo de la paz'; el que la rechace, permanecerá excluido para siempre de la salvación" (op. cit., p. 1202). Por eso, la personificación es un recurso retórico que expresa adecuadamente la densidad, el peso divino de los bienes ofrecidos. Porque de eso se trata: sólo se ofrece la paz, la presencia 
inmediata de Dios, en son de paz, o más aún, como plenificación sobreabundante de los más hondos deseos humanos. Es elección porque la paz es una alianza, que el ser humano tiene que ratificar personalmente y que, por eso mismo, puede también recusar. Pero lo que se ofrece es sólo salvación. Jesús es un puro sí, el sí de Dios a todas sus promesas (2Cor 1, 19-20).

La misión no es, pues, un emplazamiento, sino obra de paz, que convierte en dichosos a los emisarios (Mt 5, 9), en hijos del Dios que se revela en Jesús como Dios de paz, como comunicador de salvación. En este sentido, hay que enfatizar que la misión no es cristiana, cuando el misionero no lleva el mensaje en sí mismo y para los demás como una buena y alegre noticia: la noticia de la salvación incondicional de Dios. Éste era para Las Casas el punto stantis aut cadentis de toda la mision cristiana, de tal modo que una misión con contendidos materiales exactos no era, sin embargo, participación de la misión de Jesucristo, si no relucia en ella la calidad de evangelio. La conclusión obvia que él sacaba es que la primera predicación no podía consistir en echar en cara pecados, sino por el contrario, proclamar el perdón y la gracia. Toda misión cristiana debe estar impregnada de gracia y salvación, no sólo en los contenidos, sino en el modo de acontecer.

Por eso, van llamando a la puerta. Es que vienen de parte de un Dios desarmado, que respeta absolutamente la libertad: quien no entra por la puerta es un salteador ( $\left.\mathrm{Jn}_{\mathrm{n}} 10,1\right)$. Llama quien no es prepotente, quien viene desde abajo y viene en son de paz. Hasler insiste en que el concepto lucano de paz se elabora en contraste "con la ideología de la pax imperial" (p. 1203). La paz que proclaman los ángeles, en el nacimiento de Jesús, descalifica la paz de Augusto. Si la paz de Augusto fuera considerada por Dios como verdadera paz, la proclamación angélica de la paz no tendría razón de ser. Esto es tanto más llamativo cuanto que la apoteosis de Octavio se debe, precisamente, al hecho de haber trádo a la tierra el don divino de la paz. Por eso, la multiplicación de estatuas suyas con las ropas sacerdotales, ofreciendo la ofrenda eucarística, por el advenimiento, tras tantos siglos de buscarlo y pedirlo en vano, de ese don divino tan necesario y deseado por la humanidad. La paz imperial se logra con las legiones romanas, la paz de Dios la canta una legión, desarmada, del ejército celeste, y se la revela a los pastores, esa masa sin peso en la historia, según el sentir de los vencedores. La paz está en un niñito recién nacido, recostado en una pesebrera. Esa misma paz de Dios proclaman jubilosos los discípulos, cuando Jesús entra como mesías pacífico a Jerusalén, montado humildemente en un burro $(L c 19,38)$. "Lucas va más allá de los rasgos davidicos y declara que aquel que entra es el Dios-Rey. Por medio de él, se difundirá, desde Jerusalén, sobre los gentiles la verdadera paz del reino de Dios, en contraste con la paz de Augusto" (op. cir. p. 1204). Por eso, a este rasgo de llamar respetuosamente a la puerta, hemos de unir la total desnudez de los emisarios. Ése es el modo adecuado de proclamar la paz de Dios que no es, como la de los imperios, el 
resultado de la imposición de los más astutos y mejor dotados (al menos para triunfar sobre otros establemente), sino un don incondicional del cual es por- tador alguien que puede caracterizarse a sí mismo como "de corazón manso y humilde" (Mt 11, 29), lo cual no implica ningún tipo de pusilanimidad, ni minusvalía, sino la posesión de una libertad serena, que no se impone, y da lugar a la propia libertad.

Así, pues, la paz, como contenido de la misión, no es efecto de ninguna persuasión psicológica, ni de dejarse moldear por la propaganda o de sujetarse a algún tipo de heteronomía, ni es la paz de los políticos, ni la de los ricos, ni poderosos, ni la de ninguna institución sacralizada, ni siquiera la paz del que se somete a la heteronomía de Dios. No hay heteronomía, porque no hay exterioridad, ni sometimiento: Dios en Jesús y por medio de su enviado es el que viene a la casa y al corazón de cada quien a reinar. Es un Dios que no quiere súbditos: se da generosamente y acepta con alegría a quien le abre el corazón.

Si los aceptan en la casa, es decir, si los reciben como enviados de ese Dios, que Jesús hace presente, ellos entregan, junto con el mensaje del reinado de Dios, los bienes salvíficos que trae aparejado: como el Dios de Jesús es el Dios de la vida como don, su presencia desaliena (expulsión de demonios) y sanea los ambientes, los corazones y los cuerpos (curaciones).

Bonnard subraya este sentido fuerte que tiene la aceptación: "Recibir a un apostol (v. 14) era al mismo tiempo escuchar sus palabras, es decir, hacerlas propias, creer. Tal hospitalidad no era una simple cortesía que no compromete" (p. 228). Por eso, para él la variante mateana, que califica de "digno" (Lucas dice "hijo de la paz") a quien los recibe, tiene este sentido preciso: "personas susceptibles de recibir (v. 14) la predicación del reino, cualquiera que sea su nivel moral y religioso; esta apertura a la predicación evangélica no es tanto una cualidad previa cuanto una disponibilidad para escuchar y creer" (p. 228).

Esta distinción nos parece decisiva para la misión de todos los tiempos. Lo que cuenta no es el grado de instrucción religiosa o de observancia moral, sino la apertura vital. Parece razonable pensar que, si el espíritu religioso es auténtico y la moral alcanza la trascendencia ética, ambos serfan factores que estimularían la radical apertura al designio de Dios. Pero el hecho de que quienes se cerraron históricamente a Jesús y a sus enviados fueron, precisamente, los expertos en religión y los que se tenían a sí mismos y eran considerados por los demás como intachables, hace ver la ambigüedad e incluso la pecaminosidad inherentes a la práctica de la religión y de la moral. Jesús se refiere constantemente a esta paradoja e incluso la radicaliza, y ella constituye uno de los ejes del evangelio de Juan. Volveremos sobre el punto.

Al hablar del sentido de la misión, ya nos hemos referido a la unión inextricable entre la proclamación verbal del reinado de Dios y la autoridad y 
energía que lo hacen presente. Hemos insistido en cómo Jesús habilita a sus heraldos, para que lo representen con toda densidad y verdad. Esta capacitación es en orden a hacer realmente presente esta soberanía saludable de Dios que proclaman. Así, pues, la proclamación del mensaje es buena noticia no sólo por su contenido (que es la gracia y no el juicio; que no es instaurar un reino político, sino reinar de verdad en los corazones), sino, más aún, porque ese contenido se comunica en toda su realidad. En las palabras y la presencia del mensajero del reino, Dios entra realmente en esas vidas y en esa casa y, de un modo tangible, las salva. Eso significa concretamente la paz.

\subsection{Objetivo de la misión: instaurar la reciprocidad de dones}

Y entonces ¿qué sucede? Que los que han recibido el don de Dios dan a los enviados el don de su hospitalidad como expresión connatural de su alegría evangélica. Ésta es la meta a la cual apunta toda la misión. Por una parte, los misioneros, porque están en manos de Dios, se ponen en las manos de quienes se abren a Dios. Por otra parte, quienes han creído en la palabra de los mensajeros y se han puesto en manos de Dios, se convierten de scres que necesitan ser animados por otros con espíritu capaz de dar vida, es decir, en mediadores de Dios para con sus emisarios. Se instaura así un círculo de bendiciones, que restaura la humanidad y culmina la creación. Entonces, son los seres humanos, en verdad imagen y semejanza de Dios: la reciprocidad de dones que instauran como modo renovado de existencia es el trasunto de la generosidad divina.

En esta dirección se mueven diversos comentarios de los exegetas. Dice Jeremias que se manda renunciar a las provisiones "para confiar plenamente en la hospitalidad". Es como si Jesús les dijera, refiriéndose al Padre: "no os preocupéis, él os abrirá hogares hospitalarios" (p. 276). En el mismo sentido, para Schmid, la confianza en Dios se expresa como confianza en los destinatarios de la misión: "hacen el camino con la tranquilidad de su confianza en Dios (cfr. Mt 6, 25-34), debiéndose confiar a la hospitalidad de aquéllos a los que precisamente llegan" (Schmid a, p. 175). Si el que confía en Dios (y por eso, va sin nada) debe confiar en el que lo recibe, como enviado suyo, es porque el que cree en el enviado se convierte a su vez en mediador de Dios para con él.

Así entendida, la misión viene a ser una de las expresiones más elocuentes de la estructura encarnatoria de la salvación. Encamación como soteriología significa que la salvación que viene sólo de Dios se obra humanamente: Jesús, el salvador de Dios, es un ser humano y nos salva humanamente. Esto quiere decir que no nos salva desde fuera de nosolros, sino sembrando y activando en nosotros esa fe que salva (Mc 9, 23; 5, 34). Continuando este movimiento encarnatorio, Jesús (y en él Dios) se hace presente, en sus enviados. Y prosiguiendo un paso más, los salvados por ellos se convierten para ellos en la expresión de la providencia de Dios (Lc 12, 29-31). De este modo, al fin, todos nos 
salvamos recíprocamente, siendo uno solo el Mediador y uno solo el Espíritu que él comunica como energía de solidaridad y uno solo el Dios que obra todo en todos. A esto apunta Bovon, cuando observa que, aunque en unas casas no los recibirán, "entrarán también en casas hospitalarias y gozarán allí de aquel provechoso intercambio de bienes materiales y espirituales que menciona Pablo" (p. 648).

Si la misión se orienta toda a crear este movimiento de reciprocidad de dones ( $y$ las expresiones institucionales y estructurales correspondientes), en el cual acontece la salvación, su existencia juzgará, en definitiva, la calidad cristiana de toda misión eclesial. Desde aquí podremos ver que no hay nada más opuesto a la itinerancia cínica que la misión cristiana. El cinismo se dirige a estimular la libertad individual, entendida como autarquía, es decir, como total ausencia de lazos conslituyentes. El paradigma es el individuo absoluto, desligado de cualquier atadura social o interior. El horizonte de la misión, por el contrario, es ir engendrando el mundo fratemo de los hijos de Dios. Aquí, la persona se constituye, precisamente, por los lazos; eso sí, lazos gratuitos, voluntarios, liberadores (no lazos de opresión o dependencia), pero no menos lazos, tan profundos que caracterizan y definen a quienes los contraen, que no son ya individuos, sino hijos y hermanos.

Si éste es el sentido de la hospitalidad hacia la cual se encamina la misión de Jesús de Nazaret y de sus enviados antes de pascua, tenemos que preguntarnos si está bien comprendida en las sentencias que Lucas y Mateo (y también Pablo, por su parte) ponen en boca de Jesús para razonarla o justificarla.

Schmid asimila el sustento (que aparece en Mateo) a la hospitalidad, tal como la hemos definido, y le parece una concreción del ambiente de gratuidad, que señala taxativamente el evangelista (v. 8): "De manera expresa queda encarecido el carácter gratuito de la misión apostólica. La predicación del evangelio no puede ser rebajada al nivel de un negocio (cfr. 2Cor 2, 17)" (op. cir. p. 258). "Quien trabaja merece su sustento (en lugar del equívoco 'su salario' que aparece en Lucas). Por ello la confiada ausencia de inquietud es la actitud que se exige del misionero" ( $l b / d$.$) . Como se ve, en este contexto, el$ merecer tiene un sentido figurado, ya que la gratuidad excluye todo tipo de contrato y así todo derecho a reclamar. Por eso, la actitud exigida es de confianza, no de la seguridad que se deriva del derecho a la contraprestación.

También Bonnard se mantiene en este mismo tono, cuando glosa la expresión de que el bracero merece su sustento: "La expresión puede significar que Dios cuidará de los apóstoles, de una manera o de otra, sin excluir la generosidad humana; pero también puede contener una invitación indirecta a que los beneficiarios de la acción apostólica satisfagan las necesidades de quienes la llevan a cabo ( $c f$ r. 1Cor 9, 14; 1Tim 5, 18)" (p. 227). Es obvio que la expresión "invitación indirecta" no está en el horizonte semántico de las relaciones 
contractuales, sino en el de las de mutua benevolencia. Sin embargo, esa invitación indirecta parecería expresar ya el clima de la primitiva Iglesia, en la que los fieles reciben la instrucción de alimentar a sus responsables, lo cual supone ya un drástico corrimiento del encuadre vital prepascual. Se estaría dando un corrimiento sutil: del movimiento (que obra por su propio dinamismo: la alegría evangélica y la fuerza del Espíritu) a la persuasión institucional.

Bovon, que tiene que habérselas con el salario que aparece en Lucas, recurre para comprenderlo al Antiguo Testamento, y más en concreto, al estatuto de los levitas, en el pueblo de Dios, que renunciaban a sus bienes y recibían en cambio una porcion de las ofrendas (Num 18,31). Y concluye: "se puede admitir que la ética de los levitas (falta de fortuna y presencia del salario) se aplić a los primeros misioneros cristianos. La armonización de estos dos mandamientos, acumulación prohibida y salario legltimo, pretende (como el maná) asegurar la simple supervivencia de los creyentes y excluye por tanto toda esperanza humana de hacer fortuna" (p. 645).

No vemos en qué se pueda apoyar Bovon para atribuir a Jesús de Nazaret una asimilación de sus enviados (y consiguientemente, de su persona) al estatuto de los levitas. Nos parece que esa interpretación derriba por tierra tanto el radicalismo lucano como el del propio Jesús, mayor si cabe. Pero es que, además, ese tipo de rentismo supone el fin de la fe abierta en la providencia y del movimiento de reunión y de reciprocidad como los dos elementos de un sólo binomio. Ese esquema tiene como telón de fondo no la itinerancia de Jesús, sino una Iglesia establecida, como la que aparece en 1 Timoteo 5, 18, que es el texto que él proyecta sobre esta época prepascual. No cuadra de ningún modo. Como dice Schmid, caemos en el equívoco. Creo que la seguridad del salario y su exiguidad es lo que ha derivado, históricamente, en la reintroducción en la Iglesia de un cinismo edulcorado, más cercano al estoicismo: la persona muy religiosa, muy sobria, muy cumplidora de sus deberes monacales o pastorales, pero sin relaciones constituyentes y sin vivir ya de esa fe abierta en la providencia. Es el "clérigo", en su versión más pura, pero con su falta radical de trascendencia. Ése es ya un profesional honesto. Él no es un personaje que pueda anunciar con fe viva y esperanza ardiente el reino de Dios y hacer realmente presente su reinado. Un hombre así no participa de la misión de Jesús de Nazaret.

\subsection{La misión como empresa peligrosa}

La sentencia sobre sacudirse el polvo de los pies como reacción ante el rechazo recibe diversas interpretaciones. Ellas dependen de la postura sobre el carácter apocalíptico de la presencia escatológica de Jesús (o de la fuente de la tradición). Quienes lo afirman subrayan, congruentemente, el cariz de emplazamiento que tiene la misión y, por tanto, la condenación que lleva el rechazo. "El 
sacudirse el polvo de los pies significa 'que se considera el lugar como territorio pagano (levíticamente impuro) y que se rechaza toda comunidad con sus .habitantes' (Billerbeck). Ello debe constituirles 'un testimonio' (cfr. Mc 1, 44, $13,19)$ en el día del juicio futuro, de que han rechazado la salvación que se les ofrecia" (pp. 175-176). En el mismo sentido, dice Bonnard que "es un gesto de ruptura total de comunión [...] La evocación de Sodoma y Gomorra anuncia las maldiciones del capítulo 11 contra las ciudades impenitentes $(11,24) "(p .228)$. Jeremias cita a Nehemías 5, 13 y a Hechos 13, 51 y 18, 6 para recalcar la ruptura de toda comunión. E insiste en que "su actuación judicial es una función escatológica realizada prolépticamente (Mt 19, 28)" (p. 278). Esto supone que Jesús no viene únicamente como evangelio. El reino de Dios que él proclama y hace presente "viene como gracia y como juicio" ( $I b l d$.$) . "Asl como por la$ palabra personal de Jesús se deciden ya desde ahora la salvación y la perdición, así también ocurre por medio de la palabra de los mensajeros. Una de dos: con ellos entra la paz o entra el juicio" ( $I b i d$.$) .$

No estamos de acuerdo con esa interpretación. Creemos que Jesús sólo viene como salvación, y por tanto, los enviados tienen que proclamarla con todas sus fuerzas. En este sentido, hay que recalcar que Jesús no maldice a los ricos o a Jerusalén o a las autoridades que lo rechazan y persiguen, sino que se lamenta por ellos. Puede prever que no se convertirán; pero eso no le da ningún consuelo, sino un dolor casi incurable, corno el que Pablo sintió por el pueblo del cual formaba parte y al cual se sentía ligado, indisolublemente. Por eso, Jesús muere pidiendo perdón por sus asesinos y Pablo desea hacerse anatema por su conversión. Adecuadamente, expresan esta actitud los primeros discursos de los Hechos que, invariablemente, acaban ofreciendo con el perdón una segunda oportunidad. Eso significa la resurrección: mientras dure la historia está abierta la oportunidad de salvación. Ahora, eso sí, la salvación incluye el reconocimiento de Jesús como Mesfas escatológico de Dios.

El punto es decisivo. Es totalmente distinta la actitud del mensajero que ofrece con una mano la gracia y con la otra la desgracia que la del que, de ningún modo, quiere la muerte del pecador (del que se cierra a la gracia), sino que se convierta y viva. La lógica de la encamación, entendida como solidaridad absoluta, lleva a esta actitud vital. El juez está por encima de aquellos a quienes es enviado; el que sólo tiene en sus manos la salvación echa la suerte con ellos.

Hacia eso apuntan, pensamos, aunque no lo desarrollen, los exegetas que creen que el gesto posterga la decisión hasta el juicio. "No se puede pensar - dice Gnilka en este sentido- en una última invitación a la conversión" (p. 280). También para Taylor, el gesto de tener por pagano ese lugar no es una maldición, no es un testimonio en su contra, sino que para ellos: "su objetivo es hacer reflexionar y que los hombres se arrepientan" (p. 354). Del mismo modo, según Bovon, sacudir el polvo "no expresa cólera ni rencor, sino ruptura de relación y 
horror a la impureza" (p. 645). Es un testimonio sobre y no contra ellos (pp. 645-646). Crossan va más allá, al pasar de la consideración de que la frase "no debe entenderse necesariamente como una maldición" a trivializarla, interpretándola: "Si os rechazan, no os importe" (p. 406).

Creo que el rechazo sí importa al misionero, no sólo en el sentido de que puede llegar hasta el asesinato, advertencia que Crossan cree proveniente del Jesús histórico (pp. 407-408), sino en el de que sí le importa también la suerte de quienes lo rechazan. Porque el rechazo sí tiene consecuencias. El que rechacemos la condenación como una acción proveniente de Dios no significa que el rechazo de su alianza, cuando es efectivamente propuesta a una familia, a una persona o a un pueblo, no tenga consecuencias para ellos. El rechazo puede equivaler a una postergación, que ponga a la persona en crisis, hasta que se resuelva. Pero también puede entrañar una cerrazón, un endurecimiento, en definitiva, una deshumanización, que no será fácil superar.

En este sentido, una misión al estilo apostólico es siempre algo peligroso: las personas nunca quedan iguales. O se abren a los mensajeros y a Dios y cambian su vida hacia una reciprocidad de dones que la fecunda o se cierran, por el temor de perder algo absolutizado en que apoyaban su vida, y así, al cerrarse a la trascendencia y afincarse en algo relativo, se degradan humanamente. Por eso, porque objetivamente la misión es en sí peligrosa, es necesario que el misionero vaya impregnado del deseo humilde, pero irrenunciable de la salvación de aquéllos a quienes es enviado.

\subsection{El resultado de la misión arroja luz sobre ella}

El resultado de la misión (Lc 10, 17-21; Mt 11, 25-27) forma parte de la comprensión de la misma. ¿Qué pasó con ese movimiento inicial que suscitó Jesús? ¿Entre quiénes se propag6? ¿Dónde encontró resistencia?

En definitiva, fue la dirigencia del pueblo de Dios la que no recibió a Jesús. Ante todo, la aristocracia alrededor del templo. Ellos fueron los causantes más directos de la muerte de Jesús. Pero también la inteligentzia, que componían los maestros de Israel, la cual rechazó la revelación del designio de Dios y la misma imagen de Dios, que Jesús presentaba. Gráficamente queda expresada esta relación en la entrada de Jesús a Jerusalén: acuerpado y aclamado por decenas de miles de peregrinos galileos, y no recibido por los representantes oficiales de la ciudad, que eran los de sus instituciones religiosas: los jefes de los sacerdotes y los maestros de la Ley; hablando en términos de partidos, los saduceos y los fariseos.

Pero ya antes, en la primera misión galilea, se habría prefigurado esta situación: "Las ciudades, sedes de las escuelas rabínicas y de la cultura religiosa, desconocen a aquél que los 'sencillos' reconocen" (Bonnard, p. 257). 
Lucas sería el que daría el encuadre literario de la oración de Jesús (Schmid, 1981b, p. 284). ¿Qué había pasado? Los discípulos regresan felices por la , experiencia de esa autoridad efectiva sobre los espíritus, pero extrañados por la diferente acogida, que contradecía a sus expectativas. Ellos esperaban que los más asiduos a la sinagoga y competentes en la ley les abriran las puertas, reconociendo en su propuesta el cumplimiento de las esperanzas ancestrales del pueblo de Dios, y que, por el contrario, la gente más alejada de la sinagoga y menos cuidadosa de cumplir la ley de Dios, los miraría como algo incómodo y los alejaría de sí. Pero había sucedido lo contrario. Ellos habían llamado a toda clase de puertas: no podía culpárselos de ninguna discriminación. Pero, globalizando la marcha del movimiento, había resultado que éste estaba configurado por un tipo de gente que no era el esperado, en tanto que los previsibles, no habían querido movilizarse, habían rechazado la invitación.

Este resultado es tan paradigmático que Jesús lo refiere a Dios, en la única oración personal de la época de su ministerio, que se nos ha trasmitido. Sea lo que sea del hecho como oración efectiva de Jesús, lo cierto es que su contenido concuerda con muchas otras sentencias suyas y encierra algo medular de su mensaje. En efecto, lo que está oculto a los entendidos y revelado a la gente despreciada es su mensaje como globalidad. "Hace referencia, seguramente, al contenido general de la predicación de Jesús y al misterio de su mesianidad" (Schmid, op. cit., p. 285). "No los aspectos particulares o particularmente elevados o profundos del ministerio de Jesús, sino el significado real del conjunto de su obra reveladora" (Bonnard, p. 258). "El Hijo da a conocer a su Padre por toda su actividad. Al inaugurar en la tierra el reino de su Padre, cada uno de los gestos de 'autoridad' hacia los hombres (enfermos, pecadores o fariseos endurecidos) 'revela' la voluntad y el designio de Dios para la humanidad entera. Los caracteres del reino de Dios aparecen ya en las obras del Hijo" (op. cit. 259).

¿Qué significa que sea Dios mismo el que lo vele a unos y revele a otros? Schmid razona diciendo que la sabiduría de escuela "no es un presupuesto necesario para el conocimiento de la revelación, sino aún más es un obstáculo para el conocimiento de los caminos de Dios" (op. cit., p. 285). Para él, el motivo "queda claro al echar una mirada de conjunto sobre el evangelio todo: la revelación divina no puede ser abarcada por agudeza ni erudición humanas, sino sólo por la fe. Y la fe es, con mucho, más bien cosa de los sencillos que de los convencidos de la propia sabiduría. El orgullo de su sabiduría de escuela, impide a los maestros de la Escritura comprender en una actitud de fe la 'locura divina' del evangelio; así frustra Dios toda sabiduría humana" (p. 286).

Si nos seguimos preguntando todavía por qué esa sabiduría de escuela dificulta el vivir de fe, tendríanos que referimos al poder que lleva aparejada. Ese poder tiende a funcionar como fundamento de la vida y principio del obrar, es decir, como sustituto de la fe. Aunque, como el poder es sagrado, no puede 
aparecer como rival de Dios, sino como expresión de él. De ahí la ceguera (las tinieblas del evangelio de Juan) que hace casi imposible salir de la situación de pecado. Pero, si es así, no sería Dios el que frustra la sabiduría humana, sino los dirigentes quienes frustran el designio de Dios (Lc 7, 30).

Bonnard va en esta dirección, al escribir que "tomados en su conjunto, estos vv. 25-27 no significan solamente que Dios revela en general a los 'pequeños' lo que tiene oculto a los sabios (vv.25-26), sino que es ésta, precisamente, la forma peculiar en que Dios se revela por el ministerio de Jesús (v. 27)" (pp. 256-257). Y lo explica así: "No prefiere, por simpatía natural, los sencillos a las 'élites', sino que reconoce que este fracaso y el resultado que le acompaña corresponde a la esencia misma de la obra que realiza al servicio de los hombres y de su Padre: salvar a los pobres, a los que desprecian los poderosos" (p. 257). Esta revelación a los pobres es, ciertamente, polémica y expresa sin ambages la parcialidad de Dios. Pero según su voluntad, esta parcialidad no es excluyente, como sí lo es la salvación que proponen las élites, sino que en la buena nueva para los pobres, está comprendida la salvación para todos. Pero es cierto que la mayor parte de las élites "rechazan esta revelación" (op. cit., p. 260). La rechazan porque, para ellos, es un escándalo y una ofensa participar de la bendición que Dios da a los pobres. Ellos no aceptan que Dios prefiera a quienes ellos desprecian.

Así, pues, el desarrollo de la misión ha puesto al descubierto, como un resultado empírico, lo que Jesús teoriza: que él es el evangelizador de los pobres (Lc 4,$18 ; 7,22$ ). Esta propuesta de Jesús no es así ningún prejuicio: los poderosos, como representantes de una sociedad construida en base a la mediación asimétrica, que mediatiza y humilla a unos y excluye a otros, no pueden admitir la inmediación incondicional que propone Jesús. Ellos están acostumbrados a una sociedad de intercambio desigual y a sopesar en toda relación los costos y beneficios, y por eso, no pueden admitir la gratuidad absoluta de Dios que, a su vez, sólo puede ser correspondida con una entrega libre y total. Mientras los poderosos no relativicen su esquema, reconociendo personalmente a los pobres, no podrán llegar a reconocer al Dios que hace presente Jesús.

En esta situación, Dios empieza por los pobres. Por eso, Jesús empieza también por ellos. Dios y Jesús se ponen incondicionalmente de su parte. También los pobres han de salir de su postración y frustración, y han de extroyectar el esquema de los de arriba. También a ellos se les pide creer en esta buena noticia y responder a ella. Si no creen en el evangelio, no son dichosos. Pero si creen en las palabras de Jesús y sus enviados, serán movidos a responder a esa inaudita predilección de Dios, de modo que la fe en ella sea el fundamento sólido de su vida y el principio de sus actitudes $y$ acciones.

Así, pues, el resultado de la misión pone al descubierto el designio de Dios: que la misión es para los pobres. En el sentido primero, de que en Jesús Dios viene a salvarlos a ellos ( $y$ en este sentido, el evangelio es mala noticia para los 
que los oprimen, deprecian y excluyen), y, en su consecuencia natural: que ellos son los destinatarios privilegiados. Pero no son los únicos porque, según el designio de Dios, en la salvación de los pobres está la de todos. A esto se nos convoca sin exclusión. $Y$ aunque nos cueste creerlo, ésta es la mayor buena noticia que Dios nos puede dar.

\section{La misión hoy}

Todo lo dicho resulta paradigmático para cualquier misión que quiera merecer con justicia el nombre de cristiana. Pero el cristianismo no es fundamentalista: no se nos ha propuesto imitar a Jesús, sino seguirlo. Y el seguimiento es una correlación: tenemos que hacer en nuestra época y en nuestra cultura el equivalente de lo que Jesús hizo en la suya. Como las épocas y las culturas no son idénticas, es imprescindible que la fidelidad sea creativa. Para eso se nos dio el Espíritu: él es tanto el que hace nuevas todas las cosas y renueva la faz de la tierra como el que nos recuerda lo de Jesús y nos lo interpreta a la medida de las circunstancias. El Espiritu nos libra tanto del fundamentalismo desencarnado como de la adaptación oportunista. En la misión no se trata sino de lo de Jesús. Pero se lo tiene que hacer realmente presente a la situación concreta, a estas personas particulares con su densidad historica y su configuración social y las peculiaridades de la coyuntura.

\subsection{Misiones para que la Iglesia viva en estado de misión}

Comenzaremos asentando que una misión no puede ser sino la puesta de una Iglesia en estado de misión o la intensificación de esa función primordial; ya que la misión no puede ser una actividad espasmódica (un operativo) o intermitente, sino una dimensión constitutiva y la finalidad complexiva de cada Iglesia particular. Si el movimiento de reunión (cfr. Jn 11, 52) es el objetivo de su venida, una Iglesia confinada o establecida no es ya la Iglesia de Jesucristo.

El descartar que la misión se reduzca a un operativo no es cosa de declaraciones de principios; por el contrario, es algo que debe relucir en su planteamiento concreto: objetivos, duración, líneas de acción, sujetos y destinatarios, medios (métodos, materiales, acciones) y evaluación. Desde ya se puede decir que todo lo que tienda a que cada cristiano asuma su dimensión, vocación y responsabilidad misionera va en la línea de la misión de Jesús; mientras que lo que tienda a mediatizar a una parte de los cristianos, que serían correas de transmisión de lo elaborado por un grupo de expertos, no va en esa línea. No es misión cristiana la que da como resultado la constitución o el afianzamiento de un grupo de cristianos activos, en medio de una masa de meros receptores. 


\subsection{La encarnación como cambio de dirección: de la institución a donde vive la gente}

La segunda cuestión tiene que ver con la dirección del movimiento. Lo que saca a la gente de sus casas, de su ambiente, de su cotidianidad para encaminarlo a lugares considerados sagrados, invierte la dirección del movimiento de Jesús. La misión cristiana sale del propio ámbito y va a buscar a la gente ahí donde ella se encuentra. Ir a las casas para sacarlas de ellas e invitarlas a concentrarse en lugares eclesiásticos es una demostración de poder, contraria al espíritu de Jesús. La salida del Padre y la entrada en el mundo para salvarlo es una dirección que pide ser continuada sin cesar. Jesús es el que busca a la oveja perdida. Él es el que sale sin cesar abajándose, tomando la delantera, llamando a cada puerta, encontrándose con cada quien en su propio terreno, al que Jesús entra desde abajo, sin poder, como uno de tantos, respetuosamente y en tanto lo quieran recibir. Y así comienza por las casas, por los caseríos, por las aldeas, por los pequeños pueblos. De ahí pasa a las ciudades de provincia. Y de la provincia acaba por fin en la capital.

No tratamos de entender esto mecánicamente. Pero sí es cierto que la experiencia de la misión de Jesús y de sus discípulos, antes de pascua, traza una dirección general. Así como el templo y las sinagogas eran los lugares de los dirigentes, a los cuales acudía la masa, en posición subordinada (ya que ellos eran no sólo los que mandaban, sino los que poseían las reglas de juego, las claves que los de abajo ignoraban), así, Jesús propone que el designio de Dios (que él hace presente) es que Dios quiere reinar de un modo inmediato, en cada corazón y en cada ambiente que lo acoja. Su itinerancia significaba, simbolicamente, que el templo iba a buscar a cada fiel para que a la postre, por la mediación del Hijo, cada uno fuera también ese templo.

Ese cambio de dirección tiene que hacerse significativamente presente. Como en tiempo de Jesús, los cristianos de América Latina piensan hoy que la Iglesia es la institución eclesiástica, que son personalmente los curas y las monjas. La gente no se siente Iglesia, ella va a la Iglesia (al templo o a buscar al cura o a la hermanita). Es el esquema de la religion, que relativiza al cristianismo. Ya lo dice la expresión: religión católica, en ella, lo sustantivo es la religión y el catolicismo es lo que la colorea. El cristianismo empieza a ser lo sustantivo que relativiza a las estructuras religiosas, cuando los agentes pastorales, cuando la institución eclesiástica se convierta en itinerante y vaya a los ambientes de la gente y vaya sin títulos, sin poder, como una de tantas, llamando respetuosamente y entrando en lo de la gente. La propuesta no es visitar. Lo que decimos es que la evangelización se ha de realizar ahf.

S6́lo si eso (que es lo que debe llevar la mayor parte del tiempo y de las energías) se cumple y tiene un resultado positivo, podrá simbolizarse esa reunión en concentraciones en lugares especiales y en reuniones, en sitios ad 
hoc. Pero con la condición de que no se entienda lo dicho como dos pasos sucesivos, de modo que el segundo deje atrás al primero, sino como dos dimensiones constitutivas, siendo la primera permanentemente la principal.

Así, pues, la misión tiene una estructura encamatoria. Éste es el trasfondo de la itinerancia y del privilegio de las casas. No se trata de tácticas, ni siquiera de estrategias pastorales, sino de que la misión sea en verdad la de Jesús. Por eso, no es cristiana una itinerancia o un ir a las casas cuando se va como un recurso de mercadeo, cuando se va para vender mejor el propio producto. El ir donde los otros es cristiano, cuando es expresión de solidaridad. Por eso, el ir desemboca en el entrar y en el estar. Entrar en su mundo y estarse en él. Éste es el sentido paulino del hacerse todo a todos, que es completamente ajeno al oportunismo camalé́nico, que no es un modo de ahorrarse la contradicción y el escándalo, que siempre lleva la buena nueva cristiana. Que simplemente es expresión de amor, ya que el amor lleva a salir de la propia casa y a asumir lo del ser amado. Ése es, concluimos, el misterio de la encamación, paradigma de toda auténtica misión cristiana.

\subsection{Unión entre contenido, Espiritu y la persona del enviado}

La misión cristiana establece una implicación inextricable (sin confusión y sin separación) entre el contenido (el reino de Dios, revelado por Jesús, y comenzado ya al ser resucitado y exaltado por su Padre), el Espíritu, que lo hace realmente presente (en la autoridad sobre el mal y el dinamismo que restablece la vida) y la persona del enviado (un evangelizado, tocado por la mision y trasformado por ella). La unión sin confusión de estos tres elementos da a la misión cristiana su peso característico, su densidad, su santidad, en el sentido más estricto del término, y por eso, su prestancia, su capacidad irradiadora, su eficacia.

\subsubsection{Contenido: una propuesta (reinado) y una esperanza (reino)}

No es cristiana la misión que no se refiere a la decisión soberana de Dios de reinar desde ya sobre cada persona (reinado de Dios) y a su promesa de que su creación no se frustrará, sino que tendrá una realización cabal, rebosante, más allá de lo que podemos desear y concebir (reino de Dios). No es cristiana la misión que no una esta propuesta actual y esta promesa incondicional a la persona de Jesús, no sólo como su revelador y mediador para que acontezca, sino porque con él, ya ha empezado a realizarse la promesa y porque para nosotros se realizará también en él, asociados a él como hijos en el Hijo. Todo esto debe ser dicho de tal manera que sea comprensible para los destinatarios de la misión y que lo puedan percibir en su condición de buena nueva.

El contenido de la misión no es ni lo que se le ocure al misionero, ni el catecismo de la doctrina cristiana, sino esta propuesta actual, en el horizonte de esta esperanza escatológica. La misión es, pues, una propuesta personal, no un 
estudio o unos eventos. Y no cualquier propuesta, sino la de que Dios quiere tomar posesión de nuestras vidas; no como dueño y señor, por las buenas o por las malas, sino respetuosamente, salvadoramente, graciosamente, haciéndonos en Jesús sus hijos queridos. Pero esto no acontece sacándonos de este mundo pecador, salvándonos del mundo, incluso liberándonos de nuestro cuerpo material y corruptible, sino entrando él a nuestro mundo, acompañándonos en esta nuestra condición para transfigurarla desde dentro. Así, pues, la propuesta de acoger ya a Dios como Padre se da en el horizonte de esperanza para esta creación y esta humanidad. Ellas no están perdidas irremisiblemente. Más aún, ellas pueden ser salvadas desde dentro. Ésa es la relación entre reinado y reino. Quienes acogen a Dios no sólo se dejan trasformar por esta presencia salvadora, sino que ponen su vida en la salvación del mundo. Éste es el contenido insoslayable de la misión. Un contenido práxico, transformador; y por eso, un contenido que conlleva una autotransformación: la conversion. Es el cumplimiento de la profecía: "Conviértenos y nos convertiremos" (Jr 31, 18).

\subsubsection{Misión con espiritu: la fuerza actúa en la debilidad}

Pero si éste es el contenido de la misión, es obvio que la misión requiere como su condición de posibilidad la actuación del Espíritu. Sólo su presencia hace presente a Dios, sólo él nos pone en la órbita de Dios (1Cor 2, 10-12); sólo en él podemos decir con verdad a Dios: Padre ("Papadios" en nuestro lenguaje coloquial, tan exacto, en este caso) ( $\operatorname{Rm} 8,15-16$; Gal 4, 6-7). Y también sólo en él podemos confesar a Jesús como nuestro Señor $(1$ Cor 12,3). En suma, quien no tiene el Espíritu de Jesús no es cristiano (Rom 8, 9).

Ahora bien, ¿qué significa una misión con Espíritu? Pablo lo aclara a los corintios: es la fuerza que actúa en su debilidad, comunicando vida (1Cor 2, 3-5; $2 \operatorname{Cor} 4,7-14 ; 12,9-10$ ). Así, pues, la misión no se apoya en la habilidad propagandística, ni en el despliegue de un poder que se impone con su contundencia, sino en la fuerza del Espíritu, que actúa en la debilidad de los misioneros, en la de Jesús y en la de sus enviados.

Aquí hay que insistir simultáneamente en dos aspectos: el primero es que no hay misión cristiana sin despliegue espiritual; el segundo es que la autoridad, la energía y el dinamismo espiritual nada tienen que ver con la contundencia de los poderes establecidos, sino que se realizan desde abajo, en la debilidad. Si no hay energía y dinamismo, la misión no es cristiana; pero sólo es cristiano el dinamismo espiritual que se realiza desde la debilidad y no el despliegue del poder y gloria de los jefes de este sistema de vida ( $c f$. Lc 4, 6-7). Jesús rechazó el enfeudarse a ellos; y una misión que se remite a él no puede llevarle la contraria, en este punto decisivo.

En este punto es necesario hacer un corte profundo. Las misiones cristianas, hasta san Bonifacio, se hablan realizado por regla general desde abajo. Él acepta 
la protección imperial y desde ella realiza actos de fuerza, pero luego vuelve sobre sí y muere mártir. En el siglo XVI, se instaura la unión entre expansión łmperialista occidental y misión cristiana occidentalizadora. Así, el grueso de la misión americana, la de África y gran parte de la de Asia. De todos modos, aun en medio de este ambiente general, los intentos más genuinos y fructíferos siguieron haciéndose desde abajo como, por ejemplo, la evangelización de la costa de las perlas en el sureste de la India (malabares y malancares) o la de Japón o Corea (frente a las de Nobili o Ricci) o la de los hurones, en el Canadá frances, o (en parte, al menos) la de las reducciones paraguayas; o por lo que toca a Europa, la recristianización campesina desde Jerónimo Emiliano al cura de Ars o la de evangelización práxica de las ciudades que llevaron a cabo sobre todo las congregaciones religiosas femeninas, en el siglo XIX.

Esto no significa desautorizar sin más el uso de los medios masivos de transmisión, pero sí implica no utilizarlos acríticamente, adaptativamente, sino desde el ethos y el pathos de lo que se transmite. Y significa también que su papel es complementario, ya que no pueden sustituir esa entrega personal del mensaje, y sobre todo de su realidad, aunque sí puede prepararlas.

\subsubsection{El enviado es interior a la misión}

Con esto entramos en el tercer elemento, indisociable, insistimos, de los otros dos: la persona de los misioneros. Ella entra en este conjunto, obviamente, como portadora del mensaje del reinado y el reino. Pero ella no puede ser sustituida por otros vehículos del mensaje (como podría ser un libro, un folleto, unas guías, una colección de videos), porque no es mera correa de transmisión de unos contenidos (en definitiva, anteriores y exteriores a él), sino el portador del Espíritu, que da espesor de realidad y peso al mensaje.

Si el Espíritu no es un elemento de este mundo, entonces, no actúa como un elemento más, objetivadamente. El Espíritu sólo actúa a través de las personas (y de creaciones personales tan personalizadas que sean capaces de retenerlo). Por eso, insistíamos en que los evangelizadores son tan inherentes a la misión como su contenido y como el Espíritu. Es que el Espíritu sólo puede actuar a través de ellos. Pero no de ellos como meros instrumentos. El Espíritu no se sirve de nadie, no se aprovecha de él, no actúa a pesar de él. Actúa activando, animando, inspirando, fortaleciendo..., en definitiva, personalizando al evangelizador, desde más adentro que lo íntimo suyo. De modo que, en un examen científico, el Espíritu es indetectable: todo queda explicado por las energías inusitadas, por la creatividad excepcional, por la capacidad fuera de lo común de conectar con las personas, por la tenacidad a toda prueba... Desde la fe, comprendemos que es el Espíntu el que activó todos esos dones, que como cualidades inexploradas yacían en lo profundo de esa persona, hasta que, entregándose a ese dinamismo espiritual, todo se fue poniendo en movimiento. Esta 
actuación desbordante, tan característica de los santos, les causa una tremenda sorpresa que raya a veces, en muchos casos, en el desconcierto y que acentúa siempre la impresión de desproporción entre lo que perciben que son ellos de suyo y lo que ven que sale de ellos, que no dudan en atribuir, certeramente, a esa gracia de Dios.

En resumen, los evangelizadores son intemos a la misión, no por la posesión de cualidades extraordinarias o de una especial excelsitud moral, sino porque, al ponerse en manos de Dios, se han abierto completamente a la actuación del Espiritu, en sus vidas. Los que llaman a las casas son los que previamente han abierto las puertas de sus corazones al Dios de Jesús, a Dios en Jesús, como les sucedió a los primeros discípulos. "El recuerdo de las grandes evangelizadoras y de los grandes evangelizadores, que fueron antes grandes evangelizados, pone de manifiesto cómo, para afrontar el mundo de hoy hacen falta personas entregadas amorosamente al Señor y a su Evangelio" (VC 81).

Así, pues, la evangelización no acontece a través de expertos en técnicas de mercadeo, preparados en cursillos intensivos, dados por especialistas. La misión sólo puede ser la comunicación de su razón de vivir, de su tesoro, que llevan a cabo personas entregadas a Dios. Será el evangelio del reinado y del reino de Dios, pero según el evangelizador. Es cierto que "la fe se fortalece dándola" $(R M 2)$, pero esto implica que la misión está enfocada a la comunicación personalizada de la fe como una llama prende otra llama.

\subsection{La misión instaura la reciprocidad de dones}

La misión instaura la reciprocidad de dones. Por una parte, quien va a la misión puesto en las manos de Dios, se pone también en manos de quienes aceptan el reinado de Dios. El vivir de fe (fe en Dios, suscitada por Jesús) lleva en la dirección de la fe humana y la posibilita. Por otra parte, quien, dando fe a la palabra del mensajero, abre su vida a Dios y lo experimenta como presencia sanadora y plenificadora, tiende a expresar su alegría y agradecimiento acogiendo al mediador de esa salvación experimentada. Así, pues, también para él recibir a Dios, conlleva recibir a su enviado. Por ambas partes, el impulso al otro nada tiene que ver con el cumplimiento del deber, ni con el hacer méritos ante Dios, ni menos aún con un contrato humano. La fe humana es expresión de la alegrfa divina, la acogida al otro es concomitancia de la acogida al Otro. La filiación se expresa como fratemidad.

Por eso, la misión constituye a la Iglesia y la misión es la finalidad de la Iglesia, y la finalidad de la misión tiene ese rasgo de definitividad, que no tiene la Iglesia (como institución y como sacramento). El designio de Dios de hacernos a todos hijos en el Hijo, y de hacer así de la humanidad dispersa y dividida una familia de pueblos y, en definitiva, un pueblo de hermanos, desborda a la Iglesia y la Iglesia está a su servicio; y cuando el objetivo se cumpla, ya 
habrá desaparecido la Iglesia y sólo quedará el mundo fraterno de los hijos de Dios. Esa será la nueva tierra, la nueva humanidad, la nueva creación.

- Pero no habrá vida perdurable, si no se ha sembrado ya la fratemidad, en este mundo. En el otro sólo se cosechará lo que haya sido sembrado aquí. Hay muchos modos de hacerlo. La misión tiene el privilegio de la complexividad: une filiación y fratemidad, en Jesús, Hijo único y primogénito de muchos hermanos.

Históricamente, tenemos que reconocer honradamente que no todo lo que en el cristianismo se ha llamado misión ha tenido como objetivo, ni como resultado, un aumento de fratemidad. No pocas veces, al acabar la mision, ha habido más personas que han aceptado el yugo de la institución eclesiástica y se han sometido a su normativa. La imagen plástica es la concentración final, que no refleja alegría, sino disciplina y acatamiento costosos. La multitud, rendida a un Dios que perdona, pero que también exige. $Y$ entre esas exigencias está el sometimiento al estamento clerical. Así, la muchedumbre está apiñada en tomo a la institución y al Dios que ella representa. Pero no están juntos unos con otros. El Dios de la institución no les ha llevado a reconocerse unos a otros, a conllevarse en la fe, en el amor fratemo y en la vida cristiana. Es que ese Dios no era el "Padre nuestro" (Mt 6, 9), sino el Patriarca de los patriarcas, en esta sociedad de patrones y clientes. No es el Padre que no tiene representantes, que se revela en la fraternidad, en el seno de la cual los representantes de su Hijo se reconocen por su servicialidad desde abajo (Lc 22, 24-27; Jn 13, 13-17). Estas misiones no han sido cristianas. No podemos seguir haciendo misiones así: misiones sin "Papadiós" y sin fraternidad, y por eso, misiones sin Espíritu, es decir, sin libertad (2Cor 3,17), montadas en base a la coacción con el fin de inducir conductas (pautas introyectadas, desde el poder) y reforzar así el predominio de la institución.

La misión será cristiana cuando cada uno de sus elementos y la estructura que los vertebra se dirija a sembrar fe divina y, por tanto, fe humana, a que las personas se pongan en manos de Dios y en manos de quienes abren a Dios sus corazones; en suma, a sembrar la fraternidad de los hijos de Dios. La Iglesia no es otra cosa que su sacramento.

Esta reciprocidad de dones como propuesta trascendente no excluye el funcionamiento del mercado (basado en el intercambio, que mira, por el contrario, a) provecho del propio sujeto); pero sí, su pretensión trascendente. Desde el esquema cristiano, el mercado ni puede extenderse a todo, ni en su propio ámbito es absoluto, es decir, desligado de cualquier otra consideración. Si la misión no quiere acomodarse al mercado, con lo cual se devalúa completamente, no puede perder de vista esta tensión: existe la reciprocidad de dones y el intercambio; ambos son dos lógicas distintas. Si la vida no puede seccionarse (no existen los dos reinos, sino que ambos están mezclados, tanto en la Iglesia como 
en el mundo), una de las dos lógicas ha de llevar la voz cantante. Para el cristianismo, ésa debe ser la lógica de la reciprocidad de dones. Ésta es la cruz de la misión actual.

\subsection{El privilegio de los pobres en la misión}

Esta cruz se expresa como privilegio de los pobres. Esta expresión es hoy incomparablemente más escandalosa que hace cuarenta y hasta veinte años. Por eso mismo, es mucho más necesaria, en la misión actual.

Los pobres entran en la misión de dos modos. Ante todo como contenido. Como decía Bonnard, "salvar a los pobres": "corresponde a la esencia misma de la obra que realiza al servicio de los hombres y de su Padre" (p. 257). No se trata de afurmar que Dios no discrimina y que, por eso, salva también a los pobres. Por el contrario, en este mundo en que los pobres son excluidos por los poderosos, Dios interviene, poniéndose de parte de ellos. Así, pues, el Dios que se revela en Jesús salva, en primer lugar, a los pobres, y luego hace partícipes a todos de la salvación de los pobres. Es decir, la salvación de los demás está en reconocer la salvación de los pobres y conectarse con ella. Frente a la propuesta vigente que sostiene que la salvación de los pobres (de algunos) no podrá darse sino como redundancia o desborde de la salud del sistema, la misión de Jesús (y por consiguiente, la misión cristiana) proclama que la salvación de los no pobres acontecerá como participación de la salvación de los pobres. Esto hoy suena a necedad. Pero la misión dejarla de ser cristiana, si se avergüenza de este designio de Dios y lo oculta y lo deja de lado o (lo que es peor), pasándose al esquema establecido, lo reinterpreta como paliativos a los efectos más destructivos del sistema.

Pero, si creemos realmente que éste es el contenido de la misión, inevitablemente, se lo tenemos que comunicar a los mismos pobres. De este modo, los pobres entran también en la misión como sus destinatarios privilegiados. Si como contenido decía Jesús que el reino es para los pobres (Lc 6, 20), como destinatarios, afirmaba que él había sido enviado para evangelizar a los pobres (Lc 4, 18; 7, 22).

¿Qué significa, en concreto, evangelizar a los pobres? Decirles creiblemente que Dios los ama con un amor respetuoso y tierno, de modo que es su Dios y quiere que ellos lo tengan como suyo. No es que también es su Dios, sino que es, precisamente, su Dios. El evangelizador no pobre ha de hacerles saber que su Dios es el Dios de los pobres, que no es el Dios suyo, sino el de ellos, es decir, que él no tiene otro Dios que el Dios de los pobres. Y por eso, ese Dios de los pobres no puede llegar a ser su Dios, si no va donde ellos y si ellos no lo admiten como suyo. Así, pues, el acto de evangelizar a los pobres, si se lo entiende correctamente, es la condición de posibilidad de que un no pobre sea cristiano. Es el modo de que el no pobre participe en la salvación de los pobres, 
si los pobres se convierten a ese evangelio e instauran con el evangelizador la reciprocidad de dones.

- No ha entendido nada el evangelizador que va a los pobres llevado de una generosidad descomprometida, como bienhechor, para hacerles un favor del cual él no gana nada. El evangelista que está en el secreto del reino va donde los pobres para encontrarse con Dios, para recibirlo él mismo, al comunicar esa noticia inaudita de que Dios en Jesús se ha revelado como el salvador de los pobres, en el sentido preciso y pleno de que toma partido por ellos, les promete su reino y quiere ya reinar en sus corazones.

Es normal que muchos pobres que reciban realmente, con todo su peso y densidad, este anuncio increible, se quedarán confundidos y complacidos y abrirán, efectivamente, sus corazones a Dios, teniéndolo por su Dios. Estas personas son, ante todo, (aunque no exclusivamente), los pobres de espíritu de la tradición mateana. Ellos son propiamente los pobres con espíritu (Ellacuría pp. 129-151).

Ellos son el corazón de la Iglesia. Desde ellos debe estructurarse (o reestructurarse) la Iglesia. Éste es uno de los objetivos de la misión. Naturalmente, no estamos diciendo que ellos deben sustituir los oficios, los sacramentos y las estructuras que vienen de la primera tradición. Pero sí que el desempeño de esos oficios y la estructuración concreta de la Iglesia se lleve a cabo de tal manera que los pobres con espíritu puedan ser verdaderos sujetos y no sólo destinatarios, y así, la Iglesia de Jesucristo aparezca también en su visibilidad institucional como Iglesia de los pobres.

Esto en concreto significa para la misión dos cosas. Ante todo, que los no pobres no den cosas a los pobres (sean éstas saberes o haberes técnicos o económicos), sino que vayan donde ellos humildemente a comunicarles esa buena nueva a que nos hemos referido. Que vengan con la pretensión desarmada de ser recibidos en sus casas para que el Dios de los pobres sea su Dios y puedan participar de la bendición de los pobres. Segundo, que estos pobres evangelizados sean parte sustancial de la misión, en primer lugar, a sus hermanos, pero también a otros, que no son pobres.

Cuando llegue a instaurarse la reciprocidad de dones sí pueden dar los no pobres saberes y haberes porque, entonces, será un don que no humilla, ya que el pobre también da la salvación, que Dios le va dando.

Con todo lo dicho queda claro que la misión es un acontecimiento o (como decían algunos exegetas) un movimiento de reunión. Nada de esto es posible, si se la asimila a una programación escolar con su pensum bien especificado y su cronograma prefijado. 


\subsection{Las condiciones materiales de la misión}

Si lo que hemos dicho hasta ahora refleja el auténtico sentido de la misión cristiana, desde ello se puede entender que las condiciones materiales de su realización no son preceptos aleatorios añadidos desde fuera, sino expresión genuina de la propia sustancia de la misión.

En efecto, si el misionero no pobre tiene que decirle creíblemente al pobre que Dios es su Dios y si va a la misión porque en ello le va la vida, no le puede salir ir desde arriba, ir con todos los hierros; no va como el que es al que no es, como el que vale al que no vale. Al contrario, va como el que busca, como el que pide, como el que llama a la puerta. Y una expresión elemental de esta actitud menesterosa es despojarse de su pretendido rango para no humillar a aquellos de cuya acogida depende la propia salvación. Como se ve, esto nada tiene que ver con una téenica del mercadeo, sino que es adecuación personal al fin que se persigue.

¿Y por qué puede despojarse? ¿De dónde le puede venir el valor y la fuerza? Del deseo de su propia salvación, del deseo de ser acogido por aquel a quien ha descubierto como Dios de los pobres, en definitiva, de la fe. De este modo, el misionero que es capaz de dar la buena nueva a los pobres, es ya una persona que vive de fe. El afincar la vida en ese Dios que se busca es lo que le da libertad para despojarse con alegría. Porque ha descubierto el tesoro escondido en los pobres y no tiene pena en desprenderse de todo para adquirirlo. Esta persona sí es capaz de entrar al mundo de los pobres y de entablar con él relaciones horizontales. No se disfraza de pobre. Puede ir con su verdad, ya que no está ahí como bienhechor, sino como hermano más pequeño. Desde esa desnudez, puede dar no sólo el Evangelio, sino también con él su propia vida, ya que al ser admitido a sus casas se experimenta partícipe de la bienaventuranza del reino, destinado a los pobres.

Puestos en esta tesitura, está fuera de lugar la pregunta de qué significa hoy la prohibición de todo y el tener sólo una túnica. Desde esta pobreza espiritual no tiene caso regatear. La desnudez no es ningún precepto, sino una actitud que nace de dentro y que, progresivamente, va ganando terreno y se va expresando, según las circunstancias.

Esto también vale para el pobre con espíritu, que se convierte en evangelizador, tras haber aceptado la buena nueva. Sólo la riqueza de Dios dentro de sí es capaz de librarlo de la compulsión de promocionarse subiendo y dando la espalda a los suyos, porque esa presencia lo sana del autodesprecio y lo reconcilia consigo mismo. Si no es pobre con espíritu, el pobre no puede no utilizar la misión para promoverse a lo divino, tomando la figura de intermediario de la institución y dirigiéndose ya a los suyos desde arriba, desde fuera. Es muy difícil para un pobre ser pobre de espiritu. No es natural que un humillado sea humilde; la humillación de suyo engendra resentimiento, amargura y 
abatimiento. Si no es Dios mismo como fuente de esperanza y como presencia vivificante en el corazón, nada será bastante para que el pobre se reconcilie consigo y busque cualificarse y progresar desde lo que es. $Y$ tiene que ser el Dios de Jesús, porque un Dios como proyección absoluta de las jerarquías sociales, lo lleva más bien a estar arriba.

Por eso, también vale para el pobre evangelizar en pobreza. La pobreza es expresión no de resignación (desde ella, no es posible dar ninguna buena noticia), sino de libertad, la que da haber descubierto a Dios como su Dios. Desde esa llenumbre, también cabe la cualificación, que ya no es buscar salvación en el tener y ser así apreciado en el orden establecido, sino trasuntar a ese Dios de la vida, que quiere absolutamente convertir a este mundo en el mundo fraterno de sus hijos.

Creemos que ya existen en nuestra región estos pobres con espíritu. Ellos evangelizan espontáneamente. Pero si la misión evangeliza a los pobres, serán muchos más. Y si se los convoca sin mediatizarlos, sin enrolarlos en campañas ajenas al don recibido, sino llamándolos a que den de sí, la misión podrá ser muy dinámica.

Es en el mundo de los pobres donde se han de encontrar, para provecho mutuo y para vida del mundo, esos pobres de espíritu con estos pobres con espíritu. Éste es nuestro más querido sueño, que creo firmemente que es también el sueño de Dios para nosotros.

\section{Referencias}

Bonnard (1977). Evangelio según san Mateo, Madrid, Cristiandad. Bomkamm (1977). Jesuis de Nazaret, Salananca, Sigueme.

Bovon (1995). El evangelio según san Lucas, Salamanca, Sigueme.

Crossan (1994). Jesús: vida de un campesino judio, Barcelona, Crítica.

Ellacurfa (1984). Conversión de la Iglesia al reino de Dios, Santander, Sal Terrae.

Fitzmyer (1987). El evangelio según san Lucas, II, Madrid, Cristiandad.

Gnilka (1986). El evangelio según san Marcos, Salamanca, SIgueme.

Hasler (1996). eirene en Diccionario exegético del NT, I, Salamanca, SIgueme.

Hengel (1981). Seguimiento y carisma, Santander, Sal Terrae.

Jeremias (1974). Teologla del NT. Salamanca, Sigueme.

Juan Pablo II (1991). Redemptoris missio, Caracas, Trípode.

Juan Pablo II (1996). La vida consagrada, Caracas, Trípode.

Léon-Dufour (1982). Los evangelios y la historia de Jesús, Madrid, Cristiandad.

Manson (1975). The sayings of Jesus, Londres, SCM.

Schmid a (1981). El evangelio según san Marcos, Barcelona, Herder.

Schmid b (1981). El evangelio según san Mateo, Barcelona, Herder.

Schnackenburg (1970). Existencia cristiana según el NT, I, Estella, Verbo Divino.

Taylor (1980). Evangelio según san Marcos, Madrid, Cristiandad.

Theissen (1985). Estudios de sociología del cristianismo primitivo, Salamanca, Sígueme.

Trigo (2004). Dar y ganar la vida, Bilbao, Mensajero. 